\title{
High-dose intravenous methylprednisolone in rheumatoid arthritis
}

\author{
P. J. G. FORSTER, ${ }^{*}$ K. A. GRINDULIS, V. NEUMANN, †S. HUBBALL, \\ AND B. MCCONKEY
}

From the Department of Rheumatology, Dudley Road Hospital, Birmingham

SUMMARY Fourteen patients with severe rheumatoid arthritis (RA) were given 27 courses of methylprednisolone intravenously, each of 3 infusions of $1 \mathrm{~g}$ on alternate days. After 7 days there was marked improvement in clinical state and most laboratory tests; levels of ESR and 4 serum acute-phase proteins, C3, C4, IgG, and IgA, fell significantly. Serum IgM and rheumatoid factor titre were unchanged. ${ }^{125} \mathrm{I} \mathrm{C1q}$ binding fell in all instances where it was initially raised. Clinical remission lasted a mean of 10 weeks. Serum C-reactive protein (CRP) fell to less than $30 \mathrm{mg} / \mathrm{l}$ after all courses except one within 7 days and rose above this figure after a mean of 7 weeks. The ESR fell below $30 \mathrm{~mm} / \mathrm{h}$ within seven days in 17 courses and remained below this value for a mean of 7 weeks. Three patients had clinical remissions, with serum CRP $<30 \mathrm{mg} / 1$ and $\mathrm{ESR}<30 \mathrm{~mm} / \mathrm{h}$, lasting more than 42 weeks.

High-dose intravenous methylprednisolone (HIMP) has been compared with placebo in patients with severe and unremitting rheumatoid arthritis (RA) by Liebling et al. ${ }^{1}$ The results with a dose of $1 \mathrm{~g}$ monthly were encouraging. We had been independently studying the effects of HIMP given as 3 successive alternate-day infusions of $1 \mathrm{~g}$ in similar patients and now report our findings.

\section{Patients and methods}

We treated 14 patients (10 women, 4 men) with definite or classical RA (American Rheumatism Association criteria), whose mean age was 54 years (range 33-74) and mean duration of RA 13.6 years (range 9 months-29 years). All were initially seropositive (RA latex titre 1:32 or greater).

They were selected for HIMP because treatment with the second-line drugs, gold, penicillamine, dapsone, or sulphasalazine had not led to a satisfactory remission or had caused side-effects. No patient had evidence of peptic ulceration, diabetes mellitus, heart or renal failure, hypertension, or psychosis, and none was pregnant.

\footnotetext{
Accepted for publication 30 September 1981. Correspondence to Dr B. McConkey, Dudley Road Hospital, Dudley Road, Birmingham B18 7QH.
}

*United Kingdom Infra-Red Telescope Unit, Hilo, Hawaii. † Rheumatism Research Unit, School of Medicine, Leeds.
Six patients were receiving oral prednisolone $(7.5-12.5 \mathrm{mg} /$ day) and one intramuscular methylprednisolone ace tate ( 2 injections weekly, of $40 \mathrm{mg}$ and $20 \mathrm{mg}$ ); 2 patients were taking sulphasalazine and 2 penicillamine. The dose of second-line drugs and corticosteroids remained constant throughout the study.

Patients were admitted to hospital and given 3 intravenous infusions of methylprednisolone on alternate days. Each infusion contained $1 \mathrm{~g}$ methylprednisolone (as the sodium succinate) in $50 \mathrm{ml}$ $0.9 \%$ sodium chloride and was given over 45 minutes. Three patients received a second course, one patient 2 further courses, and one 9 courses over a period of 3 years.

Patients were assigned a clinical score of 100 immediately before admission. ${ }^{2}$ While in hospital and at each subsequent visit to the clinic, they were asked whether they felt better, much better, worse, or much worse, and the clinical score was adjusted as follows: better +2 ; much better +4 ; worse -2 ; much worse -4 . The time taken for the clinical score to fall below 100 after a course of methylprednisolone was noted.

The following laboratory measurements were made during the first week of treatment: the ESR (Westergren), serum C-reactive protein (CRP), alpha-l-antitrypsin $\left(\alpha_{1} \mathrm{AT}\right)$, haptoglobin $(\mathrm{Hp})$, orosomucoid (oro), C3, C4, IgG, IgA, and IgM, each by radial immunodiffusion. The significance of change in values before treatment from those one 
week after starting was assessed by Wilcoxon's paired rank sum test.

Immune complexes were assayed in 4 patients, in one during 4 courses, by the ${ }^{125} \mathrm{I} \mathrm{C} 1 \mathrm{q}$ method of Zubler et al. ${ }^{3}$ The upper limit of normal was taken as $3 \%$ on the basis of assays in 21 healthy subjects; this figure is substantially lower than that usually given, and while the addition of Tween to the buffer may partly explain this discrepancy we cannot completely account for it. Serum from each patient receiving methylprednisolone was stored at $-70^{\circ} \mathrm{C}$ within one hour of collection, and all samples from each patient were tested on the same day.

At subsequent visits to the clinic only the ESR and serum CRP concentration were measured.

\section{Results}

IM MEDIATE EFFECT

All patients had striking subjective improvement within 48 hours of HIMP.

Serum CRP and ESR fell significantly within 7 days of starting treatment in all 27 courses $(p<0 \cdot 005)$; CRP fell to below $50 \mathrm{mg} / \mathrm{l}$ on all occasions but one. Concentrations of the other acute-phase proteins and $\operatorname{IgG}$ and $\operatorname{IgA}$ decreased significantly, though there was no change in $\operatorname{IgM}$ (Table 1). A further notable finding was the marked decrease $(p<0.005)$ in serum C3 and C4.

In 6 serial estimations of ${ }^{125} \mathrm{I} \mathrm{C} 1 \mathrm{q}$ binding in 3 patients we found falls following treatment (Fig. 1); the fourth had a low initial binding value.

Table 1 Values ofmeasurements before and 7 days after the first dose of methylprednisolone

\begin{tabular}{|c|c|c|c|}
\hline & $\begin{array}{l}\text { Number of } \\
\text { courses }\end{array}$ & $\begin{array}{l}\text { Pretreatment } \\
\text { mean } \\
\text { (range) }\end{array}$ & $\begin{array}{l}\text { After } \\
7 \text { days } \\
\text { mean (range) }\end{array}$ \\
\hline C-reactive protein $(\mathrm{g} / \mathrm{l})$ & 27 & $\begin{array}{l}87 \cdot 6 \\
(26-218)\end{array}$ & $\begin{array}{r}7 \cdot 9^{* *} \\
(0-45)\end{array}$ \\
\hline $\operatorname{ESR}(\mathrm{mm} / \mathrm{h})$ & 27 & $\begin{array}{l}62 \cdot 0 \\
(22-115)\end{array}$ & $\begin{array}{l}27 \cdot 2^{* *} \\
(3-68)\end{array}$ \\
\hline C3 (g/l) & 20 & $\begin{array}{l}1 \cdot 49 \\
(0 \cdot 86-2 \cdot 60)\end{array}$ & $\begin{array}{c}1 \cdot 22^{* *} \\
(0 \cdot 70-1 \cdot 95)\end{array}$ \\
\hline $\mathrm{C} 4(\mathrm{~g} / \mathrm{l})$ & 25 & $\begin{array}{l}0 \cdot 30 \\
(0 \cdot 08-0 \cdot 64)\end{array}$ & $\begin{array}{l}0 \cdot 18^{* *} \\
(0 \cdot 07-0.45)\end{array}$ \\
\hline Haptoglobin $(\mathrm{g} / \mathrm{l})$ & 16 & $\begin{array}{l}4 \cdot 14 \\
(2 \cdot 50-6 \cdot 24)\end{array}$ & $\begin{array}{l}3 \cdot 67^{* *} \\
(2 \cdot 60-5 \cdot 71)\end{array}$ \\
\hline$\alpha_{1}$ Antitrypsin (g/l) & 16 & $\begin{array}{l}5 \cdot 62 \\
(4 \cdot 13-6 \cdot 86)\end{array}$ & $\begin{array}{l}4 \cdot 46^{* *} \\
(3 \cdot 35-5 \cdot 52)\end{array}$ \\
\hline Orosomucoid $(g / 1)$ & 16 & $\begin{array}{l}2 \cdot 12 \\
(1 \cdot 37-2 \cdot 66)\end{array}$ & $\begin{array}{c}1 \cdot 66^{* *} \\
(1 \cdot 30-2 \cdot 73)\end{array}$ \\
\hline $\operatorname{IgG}(g / l)$ & 7 & $\begin{array}{l}20 \cdot 2 \\
(15 \cdot 4-24 \cdot 1)\end{array}$ & $\begin{array}{l}17 \cdot 1^{* *} \\
(15 \cdot 4-21 \cdot 7)\end{array}$ \\
\hline $\operatorname{IgA}(g / 1)$ & 7 & $\begin{array}{l}4 \cdot 18 \\
(2 \cdot 89-5 \cdot 47)\end{array}$ & $\begin{array}{l}3 \cdot 64^{*} \\
(2 \cdot 65-4 \cdot 39)\end{array}$ \\
\hline $\operatorname{IgM}(g / 1)$ & 7 & $\begin{array}{l}2 \cdot 49 \\
(1 \cdot 63-3 \cdot 07)\end{array}$ & $\begin{array}{c}2 \cdot 44: \text { NS } \\
(1 \cdot 71-3 \cdot 56)\end{array}$ \\
\hline
\end{tabular}

${ }^{*} \mathrm{p}<0.01 ;{ }^{* *} \mathrm{p}<0.005 ; \mathrm{NS}=$ not significant; Wilcoxon paired rank sum test.
125

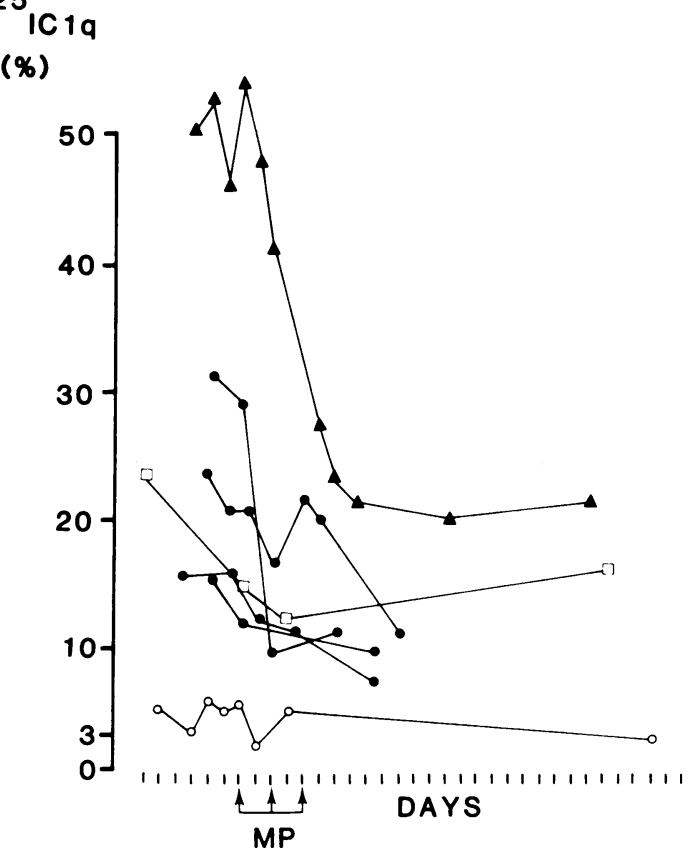

Fig. 1 The effect of high-dose methylprednisolone (MP) on serum immune complexes as measured by ${ }^{125}$ ICIq binding. Measurements made in 4 patients, in one during 4 courses of treatment.

\section{DURATION OF RESPONSE}

Two patients had symptomatic improvement lasting more than one year after single courses of treatment, and 2 courses in another patient each produced clinical remissions of at least 42 weeks. Each of these 4 episodes was accompanied by a fall in serum CRP to below $30 \mathrm{mg} / \mathrm{l}$. The remaining 11 patients returned to their pretreatment state as judged by a fall in clinical score to 100 , after a mean of $10 \pm 4( \pm S D)$ weeks.

Serum CRP fell below $30 \mathrm{mg} / \mathrm{l}$ within a week of starting all courses except one and, apart from those whose improvement lasted over 42 weeks, rose again above this value after a mean of $7 \pm 3$ weeks.

The ESR fell below $30 \mathrm{~mm} / \mathrm{h}$ within a week of starting HIMP in 17 of the 27 courses and remained below this value for a mean of $7 \pm 4$ weeks.

There was no significant change in rheumatoid factor titre during the first week for up to at least 6 months in any patient.

\section{Discussion}

The early response was the expected substantial improvement in the clinical score and laboratory measurements. About 7 weeks after the end of the majority of courses patients began to relapse, when 
serum CRP and ESR started to rise again, though after a few courses there were prolonged remissions. Clinical improvement was usually maintained for a further 2-3 weeks. These results compare favourably with those of Liebling et al., ${ }^{1}$ who found evidence of continuing response, judged by clinical and laboratory measurements, to a mean of 2.9 months after the end of treatment. However, we studied the effects of a short course, whereas they considered the effects of 6 once-monthly doses of methylprednisolone. Though we cannot state which is the best regimen, and both may have a role in the management of RA, we suggest that the response to a short course of three $1 \mathrm{~g}$ doses of the drug is useful in 2 ways. Firstly, it provides at least a few weeks' improvement under the cover of which other drug therapy, with slower-acting agents, can be initiated. Secondly, it can identify patients in whom a further course of treatment may not be needed for several months, and, further, regularly spaced doses are unnecessary.

Nonsteroid anti-inflammatory drugs improve clinical measurements but do not affect the ESR and acute-phase proteins. ${ }^{4}$ When a drug leads to improvement in both clinical and laboratory tests there is reason to believe it may have 'diseasemodifying' characteristics. ${ }^{5}$ Such seems to be the case with HIMP, for at least a period after treatment.

We previously suggested that there might be advantages in measuring more than one acute-phase protein. ${ }^{6}$ The number of patients in this study is not adequate to confirm or refute this suggestion, but it was noticeable that falls in $\alpha_{1} \mathrm{AT}, \mathrm{Hp}$, and orosomucoid were smaller than those seen with CRP. This may be because of the short half-life of CRP, but further studies might profitably take into account the likelihood of sustained remission in patients who had major falls in all, rather than just one, of these 4 proteins.

Complement components behave as acute-phase reactants, and their concentration is usually normal or elevated in RA. ${ }^{7}$ However, in severe disease, particularly with extra-articular manifestations such as vasculitis, complement levels may be low. ${ }^{8}$ This has been taken as circumstantial evidence for the concomitant presence of immune complexes. In 9 of our patients the initial serum $\mathrm{C} 4$ concentration was below our normal range $(0 \cdot 2-0.5 \mathrm{~g} / \mathrm{l})$ before HIMP. One week after the first dose serum C4 was less than $0.2 \mathrm{~g} / 1$ on 14 occasions; the decrease was highly significant $(p<0.005)$. The fall may have occurred because HIMP 'switched off' acute-phase protein synthesis, including the $\mathrm{C} 4$ response, but this alone is unlikely to produce subnormal concentrations. One possible explanation is that complement consumption continued owing to the persistence of circulating immune complexes but the previously present compensating increase in $\mathrm{C} 4$ synthesis had been blocked by HIMP. Treatment may thus have 'unmasked' increased complement consumption. However, the falls we found in C1q binding suggest that HIMP could also exert an immunosuppressive effect, albeit with a slower response.

Several patients developed a transient leucocytosis, a frequent observation in patients receiving corticosteroids. ${ }^{9}$ One patient, however, suffered pneumococcal lobar pneumonia with a leukaemoid peripheral blood picture in the week following HIMP. This resolved within 7 days, but a year later he developed acute monocytic leukaemia. J. T. Scott (personal communication) has also seen pneumonia develop soon after HIMP and clinicians should be alert to this potentially dangerous complication; close observation for a week after HIMP seems advisable. We cannot, however, confirm the $24 \%$ incidence of adverse reactions requiring medical intervention reported by Garrett and Paulus. ${ }^{10}$

We observed a variable relapse rate in our patients, but repeat doses produced a consistently good clinical response, reflected in laboratory measurements, in the 5 patients who received more than one course. We found no evidence of tachyphylaxis to the drug.

Any treatment which reduces serum CRP and ESR, particularly if it is safe, is worthy of consideration in RA, but we suggest that HIMP should be reserved for inpatient treatment of those whose disease has failed to respond to a fair trial of other disease-modifying drugs.

We thank ICI Pharmaceuticals Division and the West Midlands Regional Health Authority for support.

\section{References}

${ }^{1}$ Liebling M R, Lieb E, McLaughlin, K et al. Pulse methylprednisolone in rheumatoid arthritis. Ann Intern Med 1981; 94: 21-6.

${ }^{2}$ McConkey B, Crockson R A, Crockson A P. The assessment of rheumatoid arthritis. $Q J$ Med 1972; 162: 115-25.

${ }^{3}$ Zubler R H, Lange G, Lambert P H, Miescher P A. Detection of immune complexes in unheated sera by a modified ${ }^{125} \mathrm{I} \mathrm{C1q}$ binding test. J Immunol 1976; 116: 232-5.

4 McConkey B, Crockson R A, Crockson A P, Wilkinson A R. The effects of some anti-inflammatory drugs on the acute phase proteins in rheumatoid arthritis. $Q J$ Med 1973; 168: 785-91.

5 Editorial. Inducing remission in rheumatoid arthritis. Lancet 1981 ; i: $193-4$.

${ }^{6}$ McConkey B, Davies P, Crockson R A, et al. Effects of gold, dapsone and prednisone on serum $\mathrm{C}$-reactive protein and haptoglobin and the erythrocyte sedimentation rate in rheumatoid arthritis. Ann Rheum Dis 1979; 38: 141-4.

7 Versey J M B, Hobbs J R, Holt P J L. Complement metabolism in rheumatoid arthritis. Ann Rheum Dis 1973; 32: 557-64.

- Hunder G G, McDuffie F. C. Hypocomplementemia in rheumatoid arthritis. Am J Med 1973; 54: 461-72.

9 Finch S C, Crockett C L, Ross J F, Bayles T B. Haematological changes with ACTH and cortisone therapy of rheumatoid arthritis. Blood 1951; 6: 1034-50.

${ }^{10}$ Garrett R, Paulus H. Complications of intravenous methylprednisolone pulse therapy. Arthritis Rheum 1980; 23: 677. 